\title{
The Effect on the Swedish Real Economy of the Financial Crisis
}

\author{
Pär Österholm ${ }^{\#}$
}

* I am grateful to Anders Bergvall, Henrik Braconier, Kristian Jönsson, Jonny Nilsson, Juhana Vartiainen and seminar participants at the Ministry of Finance and the National Institute of Economic Research for valuable comments.

\# National Institute of Economic Research, Box 3116, 10362 Stockholm, Sweden

e-mail: par.osterholm@konj.se Phone: +46 84535972 
NIER prepares analyses and forecasts of the Swedish and international economy and conducts related research. NIER is a government agency accountable to the Ministry of Finance and is financed largely by Swedish government funds. Like other government agencies, NIER has an independent status and is responsible for the assessments that it publishes.

The Working Paper series consists of publications of research reports and other detailed analyses. The reports may concern macroeconomic issues related to the forecasts of the institute, research in environmental economics, or problems of economic and statistical methods. Some of these reports are published in their final form in this series, whereas others are previews of articles that are subsequently published in international scholarly journals under the heading of Reprints. Reports in both of these series can be ordered free of charge. Most publications can also be downloaded directly from the NI ER home page. 


\section{Summary in Swedish}

Denna arbetsrapport undersöker den finansiella krisens effekt på den svenska reala ekonomin. I syfte att göra detta har ett index som beskriver tillståndet $\mathrm{i}$ den finansiella sektorn konstruerats. Indexet indikerar att tillståndet $\mathrm{i}$ den svenska finansiella sektorn har försämrats avsevärt under 2008 och det befinner sig nu på den högsta nivån sedan 1990-talskrisen. Arbetsrapportens fokus ligger på krisens effekt på real BNP-tillväxt. Den modell som används för att skatta denna är en bayesiansk VAR-modell med både amerikanska och svenska variabler. Modellresultaten tyder på att den svenska ekonomin kommer att växa avsevärt långsammare de närmaste åren på grund av den finansiella krisen. 



\begin{abstract}
This paper investigates the effects of the financial crisis on the Swedish real economy. In order to do this, an index which describes the financial conditions of the Swedish economy is developed. The index indicates that domestic Swedish financial conditions have deteriorated substantially during 2008 and are now at the highest level since the crisis of the early 1990's. A Bayesian VAR model with both US and Swedish variables is used to assess the quantitative effects of the financial crisis on Swedish real GDP growth. Results suggest that the Swedish economy will grow substantially slower in the next couple of years due to the financial crisis.
\end{abstract}

JEL classification: E37, E44

Keywords: GDP growth, Bayesian VAR 



\section{Contents}

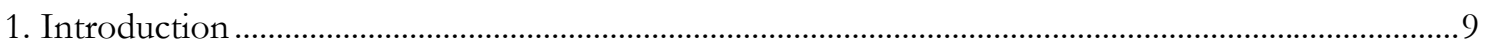

2. An index for the state of the Swedish financial markets ....................................................................10

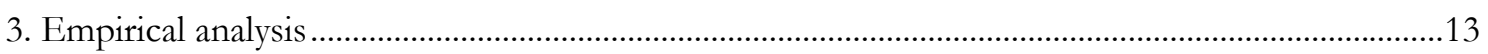

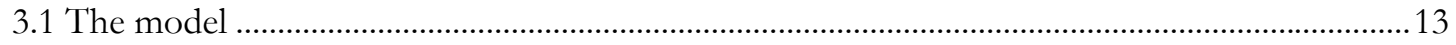

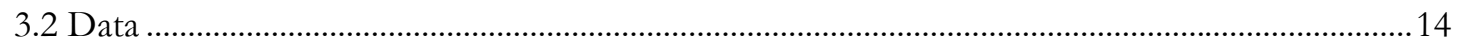

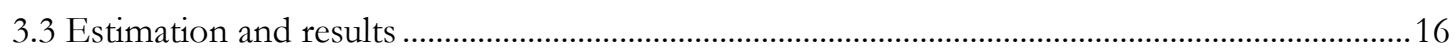

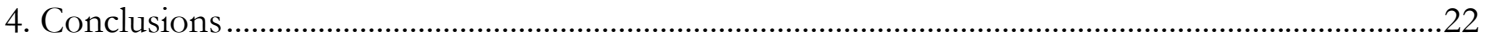

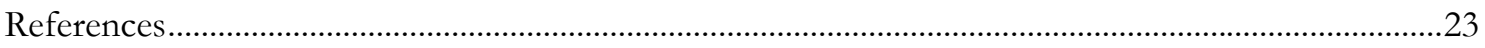

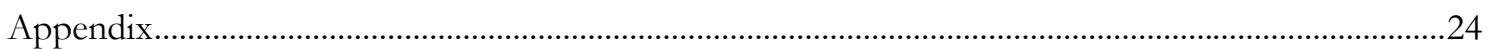





\section{Introduction}

During 2008, financial markets have been characterised by a global crisis which has its origin in the price correction on the US housing market. The background of the problem is complex but contributing factors include a number of years of highly expansive monetary policy, a political will to make home owning more widespread and overly generous credit to home buyers. The substantial securitisation that took place - in many cases with highly complex financial instruments - has, together with a high global risk appetite, spread assets related to US home loans around the world. As the US housing market has tumbled, banks and other financial institutions have experienced large losses and the lack of confidence in the financial system has led to extreme levels of interest rate spreads. The substantial decrease in risk appetite associated with the crisis has also changed the price of risk, causing large falls in stock markets globally.

Sweden has not been unaffected by the global financial turmoil. The stock market, for example, fell more than 40 percent between the beginning of 2008 and early December. However, whilst there are indications that Swedish banks may experience non-negligible credit losses in the Baltic states, they seem to have avoided large exposure to the most troubled asset types. The risk of a collapse of the financial system is the primary concern when a financial crisis hits an economy; such a collapse appears - with some assistance from the central bank and the legislative body - to be unlikely in Sweden today. Given that this crucial issue is no longer a major risk, the next concern of policy makers is typically the real economy. The question asked in this paper is accordingly what the effect of the financial crisis on the real Swedish economy will be. Our focus will be on real GDP growth, the variable that is the primary focus of most economists when discussing the real economy.

In order to investigate the effect of the financial crisis on real GDP growth, an index describing the financial conditions in the Swedish economy is developed. This is based on three variables of particular interest, namely the real interest rate, the interbank spread and the return on the stock exchange. The financial conditions index is then used in a Bayesian VAR model - together with both US and Swedish variables - to estimate the effect on Swedish real GDP growth. The information from three series is hence condensed into one index. This means that it is possible to model the relationship between the financial and real sector in a more robust way, since the issue of overparameterisation - which typically plagues high-dimensional VARs - is substantially reduced. Estimation results show that both US and Swedish financial shocks have a negative impact on Swedish real GDP growth. That the crisis has a negative effect on growth is of course stating the obvious the contribution of the paper is hence to quantify the effect and illustrate it in different ways. For forecasters in general and policymakers in particular, this information is obviously of substantial interest. 
The remainder of this paper is organised as follows: Section 2 presents an index for the conditions of the Swedish financial markets. In Section 3, the modelling framework is described, the empirical analysis is conducted and the results are discussed. Finally, Section 4 concludes.

\section{An index for the state of the Swedish financial markets}

A number of different indices for financial market conditions have been developed in the literature; see, for example, Mayes and Virén (2001), Gauthier et al. (2004), Guichard and Turner (2008) and Swiston (2008). The purpose of a financial conditions index is typically either i) monitoring of financial markets, which often can be done in real time since financial data typically are available on a very high frequency, or ii) estimation of the impact of financial conditions on other parts of the economy. In this paper, we are primarily concerned with estimation of the effects of the financial crisis on the Swedish real economy. This has obviously affected the choice of variables included in the index, since we need a long enough series to make estimation both meaningful and reliable. From an econometric point of view, it should be beneficial to weight together the information from several financial variables into one index. Using fewer variables in the model means that the relation between financial markets and the real economy can be modelled in a simpler and more robust way. This should generate better estimates of the effect on the real economy as well as improved forecasts.

Three variables are used to build the financial index presented in this paper: The short real interest rate, the short interbank spread and the return on the stock exchange. The three variables are judged to be some of the most relevant when assessing the state of financial markets and should also have predictive power for the real economy since they capture several important aspects of how a financial crisis is transmitted to the real economy. The short real interest rate represents the cost of short-term liquidity and is defined as $r_{t}=i_{t}-\pi_{t}$, where $i_{t}$ is the three month STIBOR rate and $\pi_{t}$ is the twelve-month ended inflation rate in time $t .{ }^{1}$ Both investment and consumption decisions of firms and households are functions of the real interest rate and these two variables make up approximately 60 percent of Swedish GDP. Large swings in the real interest rate can hence potentially have large effects on GDP growth, something that was painfully clear in the early 1990's when extremely high real interest rates emerged as a consequence of the attempts to defend Sweden's fixed exchange rate. The short interbank spread is defined as $s_{t}=i_{t}-i_{t}^{t b}$, where $i_{t}^{t b}$ is the three-month treasury bill rate, and provides a measure of the counterparty risk in the banking system. More generally, it is related to risk appetite and will as such be linked to tighter credit condi-

\footnotetext{
${ }^{1}$ We use realised inflation rather than inflation expectations to calculate the real interest rate, which can be motivated by agents having backward looking expectations.
} 
tions and more precautionary saving, both of which will lower investment and consumption. ${ }^{2}$ Finally, the return on the stock exchange is given by $\rho_{t}=100 \ln \left(P_{t} / P_{t-1}\right)$, where $P_{t}$ is the level of the OMX index. Obviously, the development in the stock market reflects many factors. Expected future profits can be seen as the summary measure but falling stock prices during the crisis can be an indication of a reduced risk appetite as investors abandon stocks for safer assets. In terms of the macroeconomic consequences, falling asset prices will in general generate lower consumption due to the lower wealth of households. It also means that it is harder to raise capital for firms through new share issues, which puts downward pressure on investment. ${ }^{3}$

Time series plots of the variables from 1988Q1 to 2008Q3 are shown in Figure 1 and reveal a number of interesting features. First, the short real interest rate has not reached any dramatic levels so far during the crisis. This is largely due to unexpectedly high inflation numbers lately but as energy and food prices are now coming down from earlier very high levels, inflation is likely to decrease rapidly. Second, the short interbank spread has increased substantially since late 2007 . To a large extent, this is a sign of the lack of confidence between Swedish banks that emerged as the crisis spread globally. A combination of central bank actions, government guarantees and decreased uncertainty regarding the exposure of Swedish banks to troubled assets seems to have brought down these spreads during the fourth quarter of 2008 though. Third, the Stockholm stock exchange has - like many other across the world - fallen subtantially during 2008.

Having looked at the individual time series, the next step is to generate a single index of the state of the Swedish financial markets. The return of the stock exchange initially gets a reversed sign, so that a falling stock exchange yields a positive number. The reason for this transformation is that we want a higher number of the index to indicate worsening financial conditions. The three time series are next standardised so that the mean of each series is zero and the standard deviation one. They are thereafter weighted together using the weights $1 / 3$ for all three series. ${ }^{4}$ Finally, the index is normalised to have mean 100 and standard deviation 10 over the sample. The index is shown in Figure 2. As can be seen, the index indicates that financial conditions in Sweden are the worst they have been for roughly fifteen years. However, it is also clear that the present situation is judged less serious than it was at the peak of the 1990's crisis.

\footnotetext{
2 The risk appetite aspect of the short interbank spread can also be seen by recalling that it includes flight-to-quality effects.

${ }^{3}$ Other variables - such as implied volatilities, corporate bond spreads, CDS spreads or expected default frequencies - could obviously also be of interest but long enough time series are not available for Swedish data. No measure of credit conditions similar to, for example, the Federal Reserve's "Senior loan officer opinion survey on bank lending practices" - is available either.

4 The three variables are accordingly considered equally important for describing the financial conditions. This approach can be contrasted with, for example, Guichard and Turner (2008) who base the weight a variable receives on the relative effect it has on GDP after four to six quarters. We prefer to first build the index and then investigate its effects on the real economy.
} 
Figure 1. Components of the financial index.

Short real interest rate

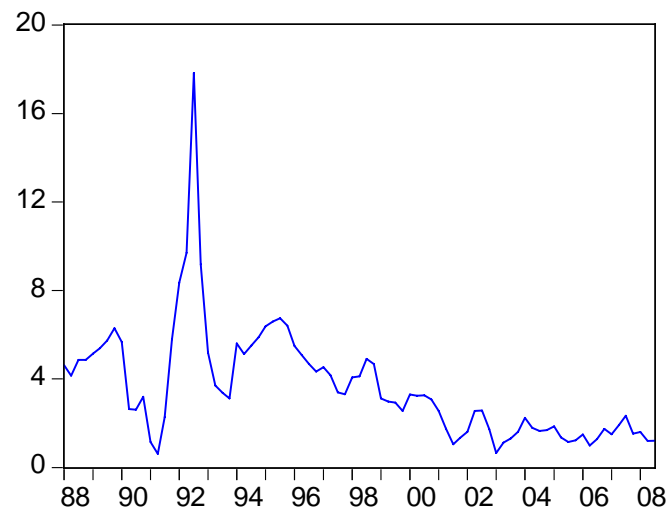

Short interbank spread

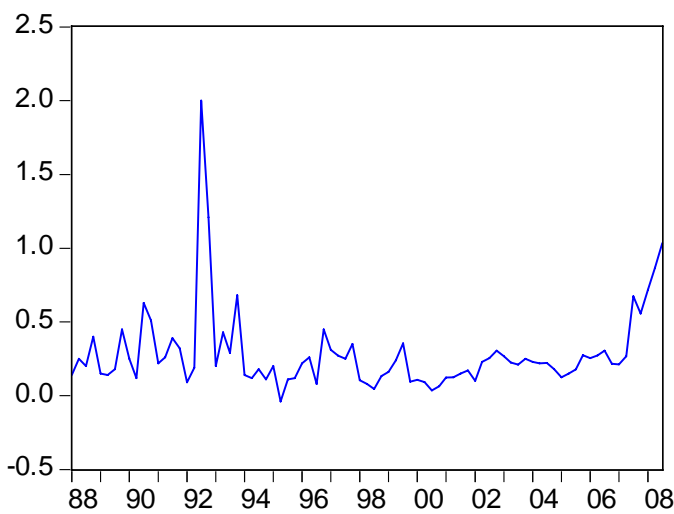

Return on OMX index

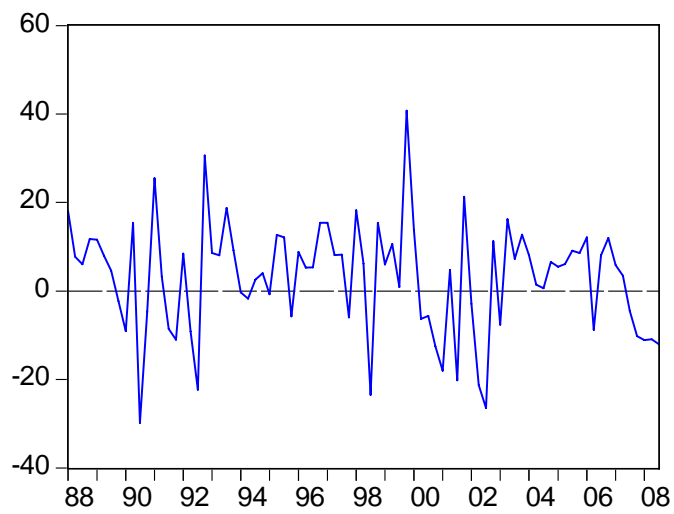

Figure 2. Financial index.

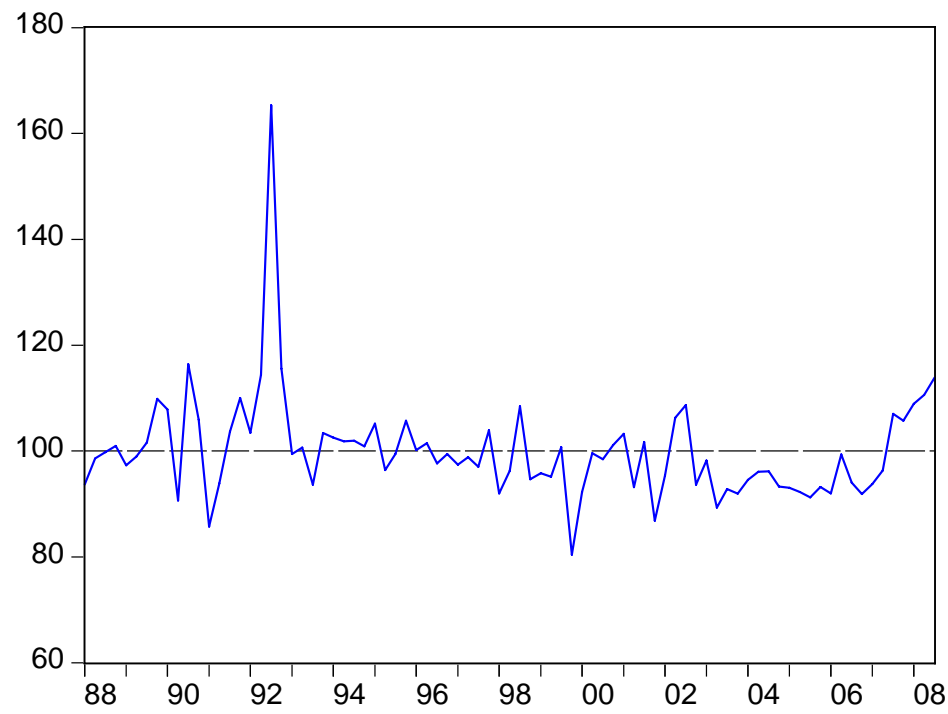




\section{Empirical analysis}

\subsection{The model}

In this paper, a Bayesian VAR (BVAR) model is used to assess the effect of the financial crisis on Swedish real GDP growth. BVAR models have become fairly popular in applied macroeconomics. One reason for this popularity is the improvement in forecast accuracy that BVARs are associated with relative to VAR models estimated with classical methods. The methodology employed has been developed by Villani (2008) and the model is given by

$\mathbf{G}(L)\left(\mathbf{x}_{t}-\boldsymbol{\mu}\right)=\boldsymbol{\eta}_{t}$,

where $\mathbf{G}(L)=\mathbf{I}-\mathbf{G}_{1} L-\ldots-\mathbf{G}_{m} L^{m}$ is a lag polynomial of order $m, \mathbf{x}_{t}$ is an $n \mathbf{x} 1$ vector of stationary macro variables, $\boldsymbol{\mu}$ is an $n \mathrm{x} 1$ vector describing the steady-state values of the variables in the system and $\boldsymbol{\eta}_{t}$ is an $n \times 1$ vector of $\ddot{i} d$ error terms fulfilling $E\left(\boldsymbol{\eta}_{t}\right)=\mathbf{0}$ and $E\left(\boldsymbol{\eta}_{t} \boldsymbol{\eta}_{t}^{\prime}\right)=\boldsymbol{\Sigma}$. The specification of the model is slightly unconventional as it is expressed in deviation from the steady state. The benefit from the approach is obvious though, as it means that an informative prior distribution for $\boldsymbol{\mu}$ often can be specified. This has, not surprisingly, been shown to be beneficial for forecasting performance; see, for example, Adolfson et al. (2007), Beechey and Österholm (2008) and Österholm (2008).

The priors on the parameters of the model used in this paper follow those in Villani (2008); the prior on

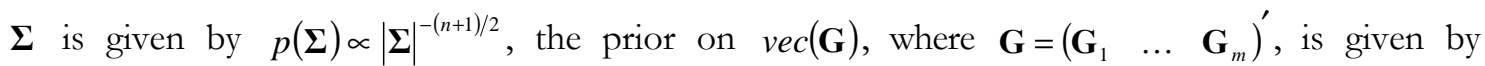
$\operatorname{vec}(\mathbf{G}) \sim N_{m n^{2}}\left(\boldsymbol{\theta}_{\mathbf{G}}, \mathbf{\Omega}_{\mathbf{G}}\right)$ and the prior on $\boldsymbol{\mu}$ is given by $\boldsymbol{\mu} \sim N_{n}\left(\boldsymbol{\theta}_{\boldsymbol{\mu}}, \mathbf{\Omega}_{\boldsymbol{\mu}}\right)$. Regarding the priors on the dynamics, the Minnesota prior (Litterman, 1986) typically employed in the BVAR literature - that is, a prior mean on the first own lag equal to 1 and zero on all other lags - is theoretically inconsistent with the mean-adjusted model, as a random walk does not have a well-specified unconditional mean. In its place, the dynamics have been modified so that the prior mean on the first own lag is set equal to 0.9 for variables that are modelled in levels and 0 for variables modelled in differences; all subsequent lags have a prior mean of zero. The hyperparameters of the model are uncontroversial and follow the literature; see, for example, Doan (1992) and Villani (2008). The overall tightness is set to 0.2, the cross-variable tightness to 0.5 and we employ a lag decay parameter of 1 . Regarding the details of the priors for $\boldsymbol{\mu}$, we return to these in the next subsection. 


\subsection{Data}

Turning to the empirical specification of the model, we define

$$
\mathbf{x}_{t}=\left(\begin{array}{llllll}
\Delta y_{t}^{U S} & H Y_{t} & \Delta y_{t} & K H_{t} & K I_{t} & F I_{t}
\end{array}\right)^{\prime}
$$

where $y_{t}^{U S}$ is the logarithm of US real GDP and $H Y_{t}$ the high-yield corporate bond spread in the United States. These variables are included because $i)$ the United States is an important trading partner for Sweden and ii) the financial crisis has its origin in the United States. Both real and financial effects that the United States has on the Swedish economy should hence be captured. ${ }^{5} y_{t}$ is the logarithm of Swedish real GDP, $\mathrm{KH}_{t}$ is a household confidence measure based on a survey by the National Institute of Economic Research (NIER) and $K I_{t}$ is a business cycle indicator based on business survey data, which also is provided by the NIER. ${ }^{6}$ Apart from having predictive power for GDP growth, it is not unreasonable to assume that $K H_{t}$ and $K I_{t}$ can provide good proxies for omitted variables in the system. Finally, $F I_{t}$ is the financial index discussed in Section 2. The data are quarterly, range from 1988Q1 to 2008Q3 and are shown in Figure 3. Taking a brief look at the financial variables, it is clear that both the high-yield bond spread and the financial index presently are at high levels. Noteworthy is also the fact both the consumer confidence and business cycle indicator have fallen extremely rapidly during the last few quarters of the sample.

\footnotetext{
5 The high-yield bond spread is sometimes interpreted as reflecting risk appetite; see, for example, Levy Yeyati and González Rozada (2005) and Österholm and Zettelmeyer (2008). It is here seen as a "sufficient statistic" for the US part of the financial crisis. No equivalent series is available for Sweden and we accordingly use the slightly wider measure that the financial index constitutes.

6 The business cycle indicator is based on a dynamic factor model used for GDP growth forecasting; see Hansson et al. (2005) for details.
} 
Figure 3. Data.

US GDP growth

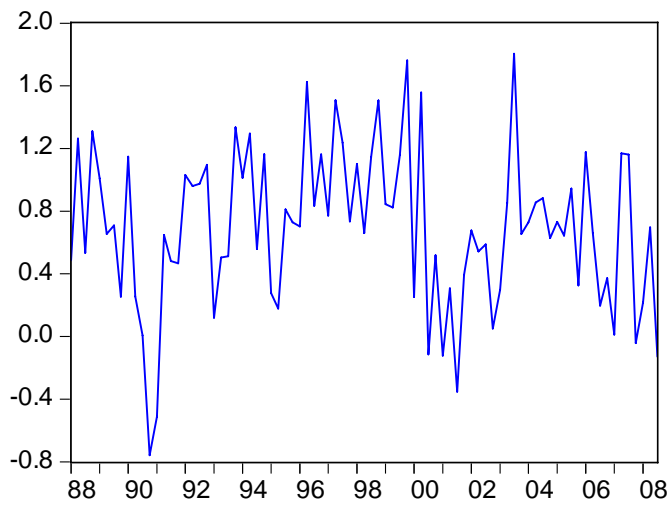

GDP growth Sweden

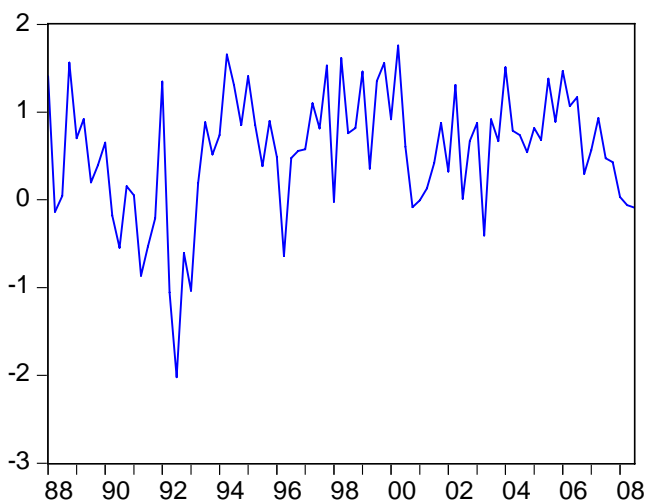

Business cycle indicator

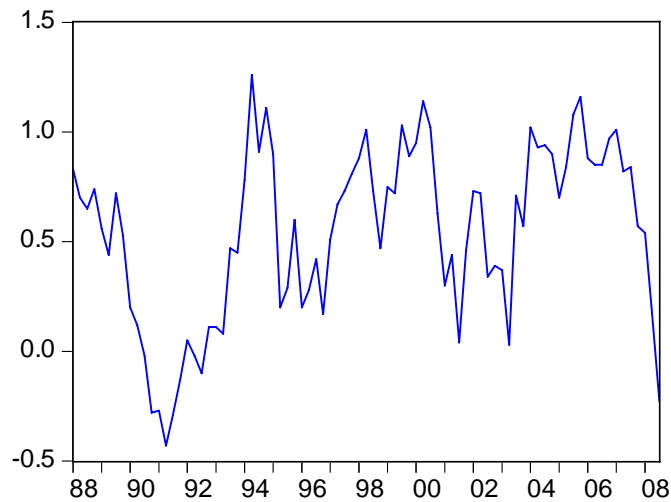

High-yield bond spread

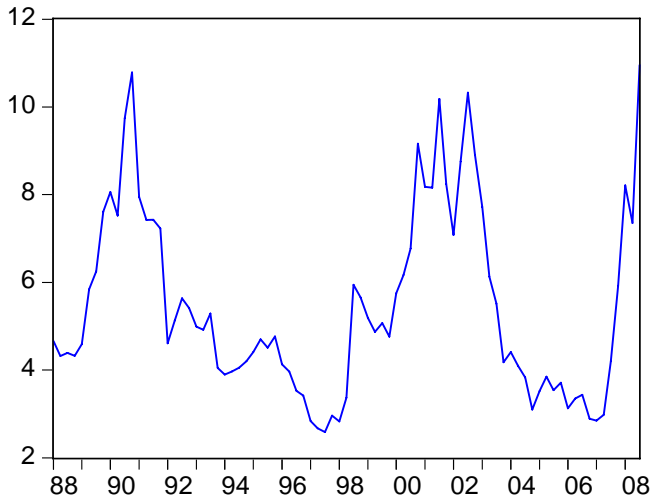

Consumer confidence

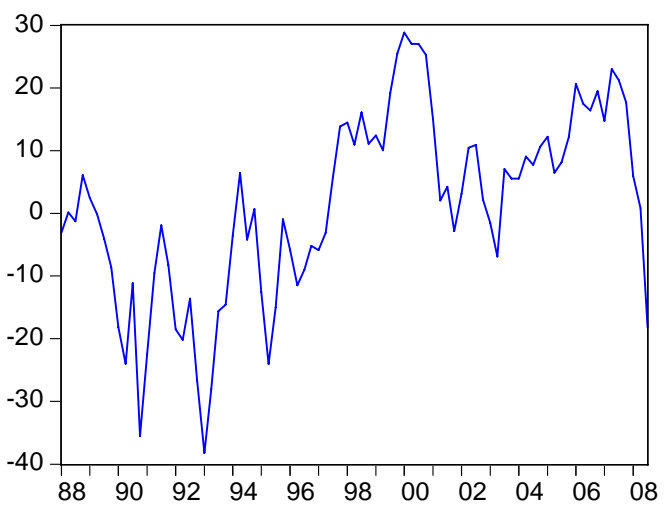

Financial index

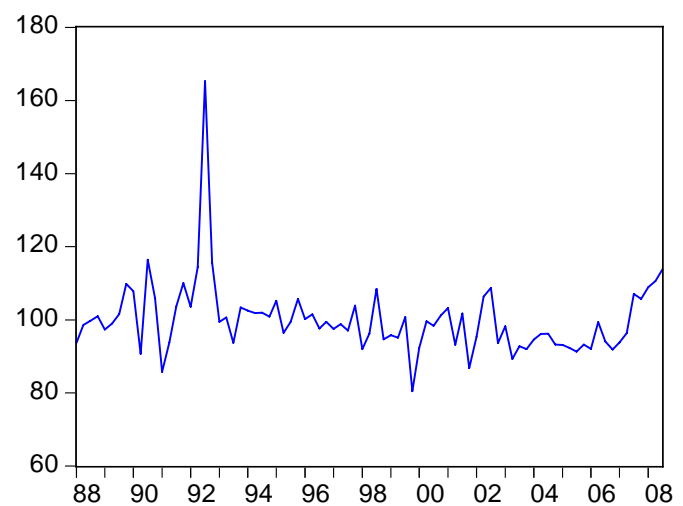

The steady-state priors are given in Table 1 and are presented as 95 percent probability intervals for the variable in question. The priors for US GDP growth and high-yield bond spread are centred on 0.625 percent and 4.5 percent respectively. These choices seem fairly uncontroversial and are similar to values suggested in the previous literature; see, for example, Gosselin and Lalonde (2006) and Österholm and Zettelmeyer (2008). Swedish GDP growth is assumed to have the same steady-state value as its US counterpart and is accordingly centred on 0.625 percent. For the consumer confi- 
dence measure and the business cycle indicator, there is less guidance to be had from theory or institutional knowledge. We hence choose to make the prior distribution less informative for the steady state for these two variables and the values are chosen such that they roughly meet the arithmetic mean of the series during the sample. Finally, for the financial index, we centre the prior on 100 seeing that this is the mean of the series by construction.

Table 1. Ninety-five percent prior probability intervals for parameters determining the unconditional means.

\begin{tabular}{cc}
\hline Variable & Prior interval \\
\hline$\Delta y_{t}^{U S}$ & $(0.5,0.75)$ \\
$H Y_{t}$ & $(3.0,6.0)$ \\
$\Delta y_{t}$ & $(0.5,0.75)$ \\
$K H_{t}$ & $(-5.0,5.0)$ \\
$K I_{t}$ & $(0.0,1.0)$ \\
$F I_{t}$ & $(95.0,105.0)$ \\
\hline
\end{tabular}

Note: Prior distributions are all assumed to be normal.

\subsection{Estimation and results}

Lag length in the model is set to $m=4$. The dynamics of the system have been discussed above but it is also worth pointing out that in the following analysis, the US variables will be block exogenous with respect to the Swedish variables. This is based on the notion that the Swedish economy is unlikely to affect US GDP growth and high-yield bond spread. This block exogeneity is achieved with an additional hyperparameter which forcefully shrinks the parameters on Swedish variables in the US equations to zero; see Villani and Warne (2003) for details. The numerical evaluation of the posterior distributions is conducted using the Gibbs sampler; ${ }^{7}$ the number of draws is set to 10000.

The issue of primary concern in this paper is the effect of the financial crisis on real GDP growth. We therefore turn to the dynamic properties of the system, where the initial focus will be on the impulse response functions. The impulse response functions are calculated using the Cholesky decomposition of the covariance matrix. We accordingly identify the orthogonal shocks $\boldsymbol{\eta}_{t}$ using the reduced-form shocks according to $\boldsymbol{\varepsilon}_{t}=\mathbf{P}^{-1} \boldsymbol{\eta}_{t}$, where $\mathbf{P}$ is obtained as $\boldsymbol{\Sigma}=\mathbf{P} \mathbf{P}^{\prime}$. The order of the variables is the same as in Equation (2). The choice of identification reflects the fact that the purpose of the paper is not to estimate a VAR where the structural shocks have "deep" economic interpretations. Rather, the goal is simply to generate orthogonal shocks corresponding to each vari-

\footnotetext{
${ }^{7}$ See, for example, Tierny (1994) for a technical discussion.
} 
able; the strategy is considered successful if the impulse response functions are in line with mainstream economic theory.

The impulse response functions are shown in Figure A1 in the Appendix. Shocks are ordered in columns and all have the magnitude one standard deviation. As can be seen, all of the impulse response functions are qualitatively in line with what one would expect. A shock to US GDP growth decreases the high-yield bond spread and increases Swedish GDP growth, consumer confidence and the business cycle indicator. It has no significant effect on the financial index though. A shock to the high-yield bond spread - where a standard deviation shock corresponds to roughly one percentage point - decreases GDP growth in both the United States and Sweden. The effect on the Swedish economy is both fairly large and drawn out. For example, Swedish GDP growth is decreased by almost 0.1 percentage point at the eight quarter horizon. The shock to the high-yield bond spread also lowers consumer confidence and the business cycle indicator. Given the degree of globalisation in financial markets, it is not surprising that it also causes a deterioration of Swedish financial conditions.

Turning to the shocks to Swedish variables, it can initially be noted that they have no effect on the US variables due to the block exogeneity assumption. Shocks to Swedish GDP growth raise both consumer confidence and the business cycle indicator though and lowers the financial index. A shock to household confidence raises Swedish GDP growth and the business cycle indicator and lowers the financial index. In a similar fashion, a shock to the business cycle indicator raises Swedish GDP growth and consumer confidence but lowers the financial index. Finally, a shock to the financial index - which is estimated to have a standard deviation of approximately seven units lowers both household confidence and the business cycle indicator. The effect on Swedish GDP growth is also negative but appears to be moderate; it dies out fairly quickly and the maximum effect is at the two quarter horizon where growth is reduced by roughly 0.06 percentage point.

Overall, we believe that the impulse response functions suggest that the model has reasonable dynamic properties. The impulse response functions provide one way of quantifying the effect of the financial crisis on Swedish GDP growth. However, a slightly more intuitive way to illustrate the effect of the financial crisis is perhaps through the following exercise: The model is first estimated using data from 1988Q1 to 2007Q4, a point in time when some signs of financial turbulence had emerged but very few forecasters were expecting worsening financial conditions or a serious downturn in real activity. The model's endogenous forecast at 2007Q4 of the high-yield bond spread, the financial index and Swedish GDP growth are given by green dashed lines in Figures 4, 5 and 6. Forecasts are generated in a straightforward manner. For each draw from the posterior distribution, a sequence of orthogonal shocks, $\left(\boldsymbol{\varepsilon}_{T+1}, \ldots, \boldsymbol{\varepsilon}_{T+H}\right)$, is drawn and used together with the definition 
$\boldsymbol{\eta}_{t}=\mathbf{P} \boldsymbol{\varepsilon}_{t}$ to generate future data. This way, 10000 forecast paths are generated for each variable.

Point forecasts are given by the median from the distribution. As can be seen from the figures, the model predicted that the deterioration in financial conditions which had taken place by then would be undone. Together with a normalisation of financial conditions, the model suggested that Swedish GDP growth would be fairly high.

Suppose that the model in 2007Q4 instead had received the information that financial conditions would worsen dramatically during the coming three quarters. By taking this information into account, a model-based forecast for Swedish GDP growth is generated under the assumption of financial turbulence. Specifically, the high future values of the high-yield bond spread and the financial index are taken into account by conditioning on the actual values for these two variables between 2008Q1 and 2008Q3.8 Forecasts from this exercise are given by the dashed black line in Figure 6. As can be seen from the figure, the assumption of future financial turbulence makes the model's forecasts of Swedish GDP growth substantially lower than what was suggested endogenously. Moreover, the forecasts are fairly well in line with the actual numbers between 2008Q1 and 2008Q3, suggesting that the model's transmission of financial shocks appears reasonable. By comparing the two growth forecasts in Figure 6, a model estimate of the effect of the financial crisis on the real economy is also provided. Quarterly growth numbers are on average a touch more than 0.4 percentage points lower between 2008Q1 and 2010Q4 when the model takes the financial crisis into account; looking at the implied annual growth rates for 2008, 2009 and 2010, this translates into growth being 1,2 and 1.7 percentage points lower in the respective years.

\footnotetext{
8 The difference between the unconditional and conditional forecasts is that in the unconditional case, the entire vector $\boldsymbol{\varepsilon}_{t}$ generated randomly at each horizon. In the conditional case, only the orthogonal shocks belonging to US and Swedish GDP growth, household confidence and the business cycle indicator are created randomly. The shocks of the high-yield bond spread and the financial index are implied by the assumed conditioning paths. For a given set of randomly generated orthogonal shocks of the variables that have not been conditioned upon and a given path of the conditioning variables, the implicit shocks of the conditioning variables and the forecasts for all variables are generated sequentially, one horizon at a time.
} 
Figure 4. High yield bond spread. Actual values and endogenous forecast at 2007Q4.

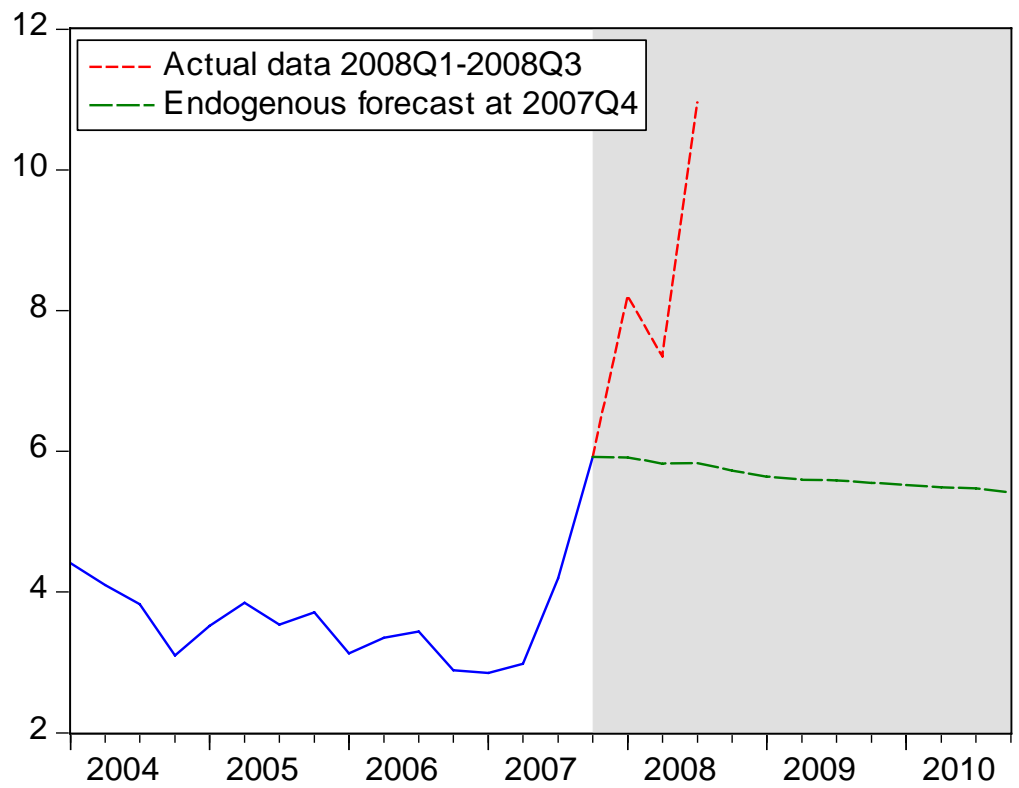

Figure 5. Financial index. Actual values and endogenous forecast at 2007Q4.

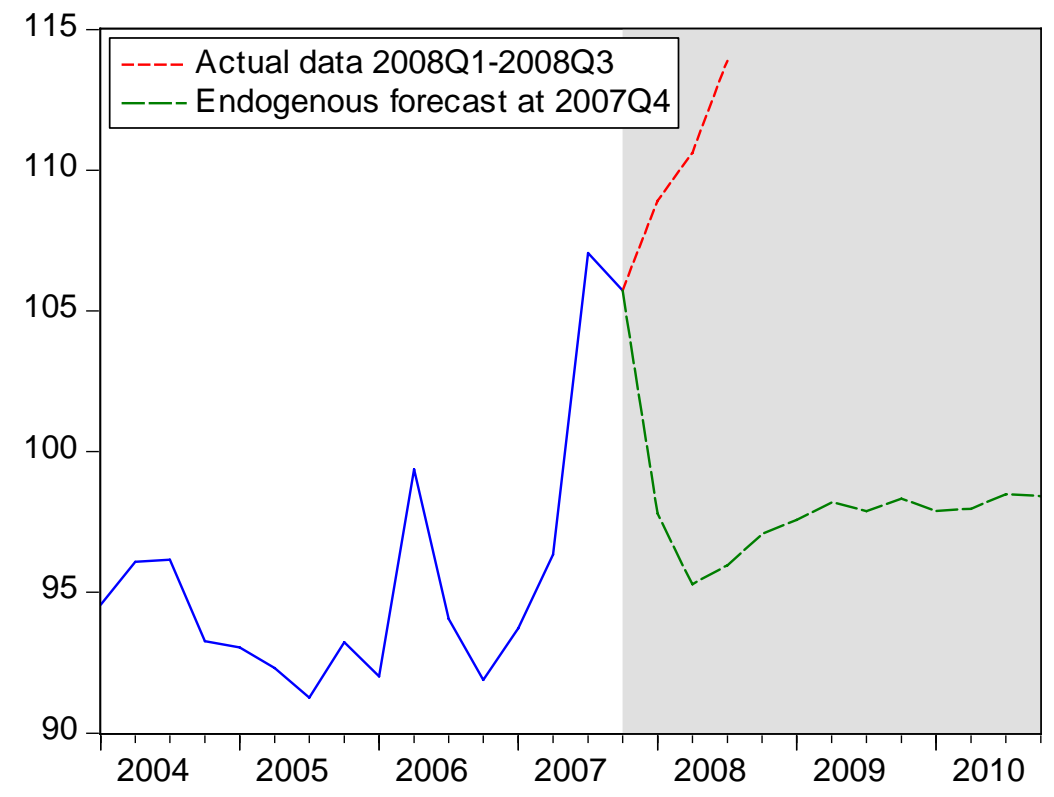


Figure 6. Swedish GDP growth. Actual values, endogenous forecast at $2007 Q^{4}$ and conditional forecast at $2007 Q 4$.

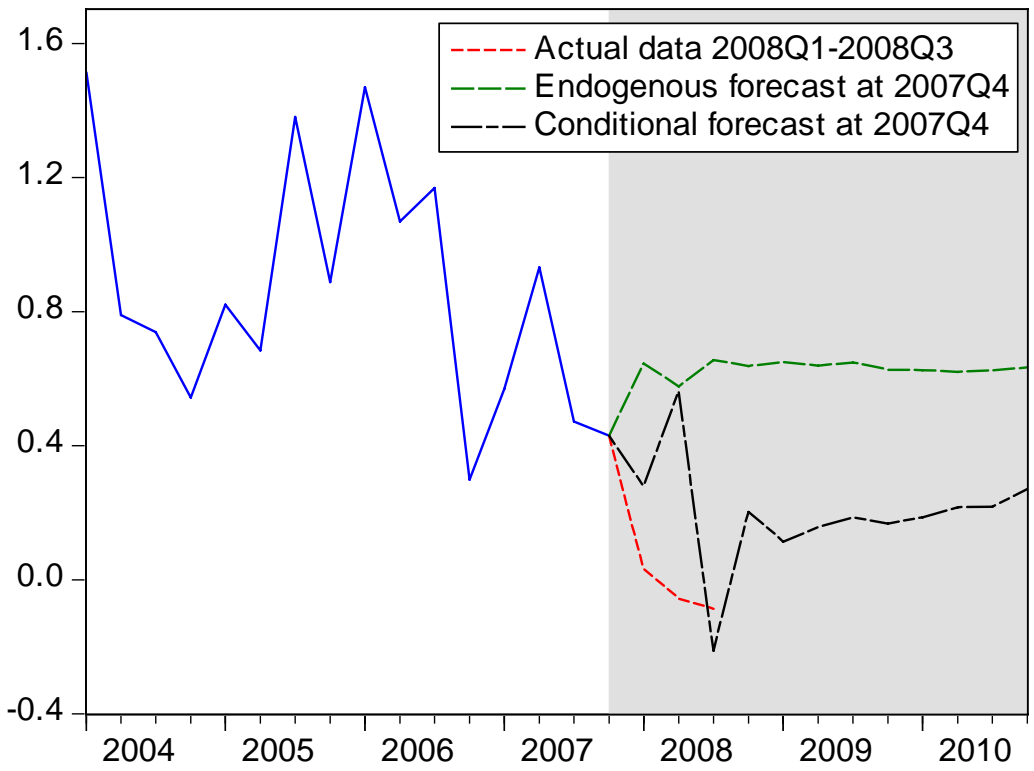

The empirical analysis has focused on quantifying the effects of the financial crisis on the Swedish economy. However, an issue of substantial interest to policy makers and forecasters is of course what the model predicts regarding future Swedish GDP growth and we finally turn to this subject. Figure 7 shows the endogenous forecast from the model standing at 2008Q3. The model predicts that GDP growth will decline even further the coming few quarters and that growth numbers will be negative during all of 2009. The recovery is predicted to be slow, with moderate growth also during 2010. Translated into annual growth rates, the numbers in Figure 7 correspond to 0.7, -0.6 and -0.1 percent rates for 2008, 2009 and 2010.

The above model-based analysis suggests that the present financial crisis will put substantial downward pressure on the Swedish real economy for quite some time to come. This is of course based on the historical patterns in the data, so a relevant question to ask is then if there are any reasons to believe that the response to shocks will be different now relative to earlier in the sample and the 1990's crisis in particular. Two aspects appear particularly interesting from this perspective, namely the external environment and the fiscal stance of the Swedish government. 
Figure 7. Swedish GDP growth. Endogenous forecast at 2008Q3.

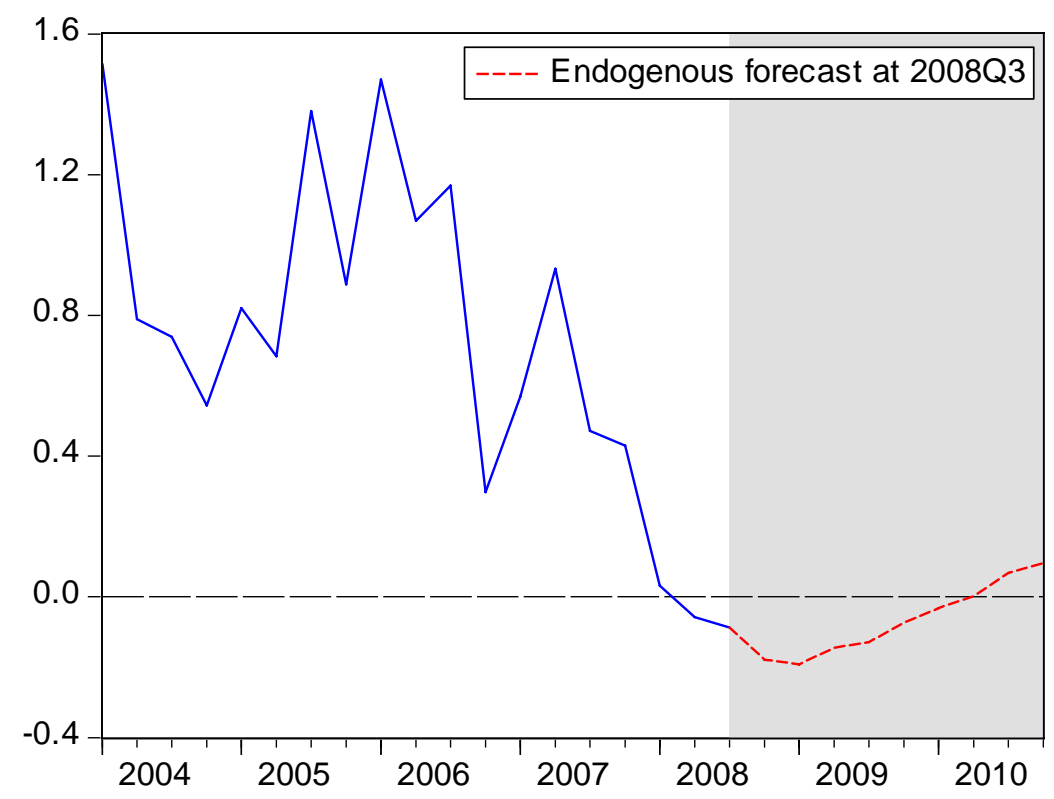

The fact that the financial crisis is global means that external demand will be weak in the near future. This could be problematic for a country with a large export sector such as Sweden and can potentially put further downward pressure on GDP growth. Moreover, the substantial depreciation of the Swedish krona that followed the abandoning of the fixed exchange rate in November 1992 had highly stimulatory effects on the Swedish economy. Effects of the same magnitude are unlikely to be seen in association with the present crisis despite the fairly large depreciation of the krona that has taken place during the second half of 2008.

The external economic environment is presently weak but the fiscal stance of the Swedish government is, on the other hand, stronger than it has been for a long time. The larger part of the 2000's has been associated with budget surpluses and the government debt has fallen as a share of GDP. Compared to the 1990's crisis in particular, this development is dramatically different; in the 1980's, the budget deficits were very large and the government debt grew rapidly. Given that the real effects of the financial crisis could be substantial, fiscal policy has - in addition to monetary policy widely been mentioned as a way of stimulating the economy. This seems like a reasonable claim, particularly as the monetary policy transmission mechanism might be less efficient than usual due to a less well-functioning financial sector. The Swedish government's ability to conduct expansionary fiscal policy in the present situation appears good and if actions are more aggressive than what historical patterns imply, the real effects of the financial crisis might be less dire than what has been suggested above. 


\section{Conclusions}

A global crisis has characterised financial markets during 2008. The magnitude of the crisis is large and many observers suggest that this financial crisis is the worst since that of the 1930's. ${ }^{9}$ Harsh financial conditions might have serious consequences for the real economy as both investment and consumption are likely to be substantially reduced. This paper has quantified the effect of the financial crisis on Swedish real GDP growth - a task which perhaps is particularly interesting from a fiscal policy point of view. Not only has fiscal policy been suggested as a way to lessen the effects on the real economy of the financial crisis but tax revenues and many expenditures - for example, those related to unemployment insurance - are functions of the development of the real economy. The econometric analysis was conducted using a Bayesian VAR model with both US and Swedish variables. Results indicate that financial shocks - and primarily US such - have substantial negative effects on Swedish real GDP growth. Forecasts from the model accordingly suggest that the Swedish economy will grow slowly the next few years.

${ }^{9}$ See, for example, International Monetary Fund (2008). 


\section{References}

Adolfson, M., Andersson, M. K., Lindé, J. Villani, M. and Vredin, A. (2007), "Modern Forecasting Models in Action: Improving Macro Economic Analyses at Central Banks", International Journal of Central Banking 3, 111-44.

Beechey, M. and Österholm, P. (2008), “A Bayesian VAR with Informative Steady-State Priors for the Australian Economy”, Economic Record 84, 449-465.

Doan, T. A. (1992), RATS Users Manual, Version 4.

Gauthier, C., Graham, C. and Liu, Y. (2004), "Financial Conditions Indexes for Canada", Bank of Canada Working Paper No. 2004-22.

Gosselin, M.-A. and Lalonde, R. (2006), "An Eclectic Approach to Estimating U.S. Potential GDP”, Empirical Economics 31, 951-975.

Guichard, S. and Turner, D. (2008), "Quantifying the Effects of Financial Conditions on US Activity”, Economics Department Working Papers No. 635, OECD.

Hansson, J., Jansson, P. and Löf, M. (2005), "Business Survey Data: Do They Help in Forecasting GDP Growth?”, International Journal of Forecasting 21, 377-389, 2005.

International Monetary Fund (2008), World Economic Outlook. Financial Stress, Downturns, and Recoveries.

Levy Yeyati, E. and González Rozada, M. (2005), "Global Factors and Emerging Market Spreads", IDB Working Paper No. 552, Inter-American Development Bank.

Litterman, R. B. (1986), "Forecasting with Bayesian Vector Autoregressions - Five Years of Experience", Journal of Business and Economic Statistics 5, 25-38.

Mayes, D. and Virén, M. (2001), "Financial Conditions Indexes", Bank of Finland Working Paper No. 17-2001.

Österholm, P. (2008), "Can Forecasting Performance Be Improved by Considering the Steady State? An Application to Swedish Inflation and Interest Rate", Journal of Forecasting 27, 41-51.

Österholm, P. and Zettelmeyer, J. (2008), “The Effect of External Conditions on Growth in Latin America”, IMF Staff Papers 55, 595-623.

Swiston, A. (2008), "A US Financial Conditions Index: Putting Credit where Credit Is Due”, IMF Working Paper 08/161, International Monetary Fund.

Tierny, L. (1994), "Markov Chains for Exploring Posterior Distributions", Annals of Statistics 22, $1701-1762$.

Villani, M. (2008), "Steady State Priors for Vector Autoregressions", Forthcoming in Journal of Applied Econometrics.

Villani, M. and Warne, A. (2003), "Monetary Policy Analysis in a Small Open Economy Using Bayesian Cointegrated Structural VARs", Working Paper No. 296, European Central Bank. 


\section{Appendix}

Figure A1. Impulse response functions.
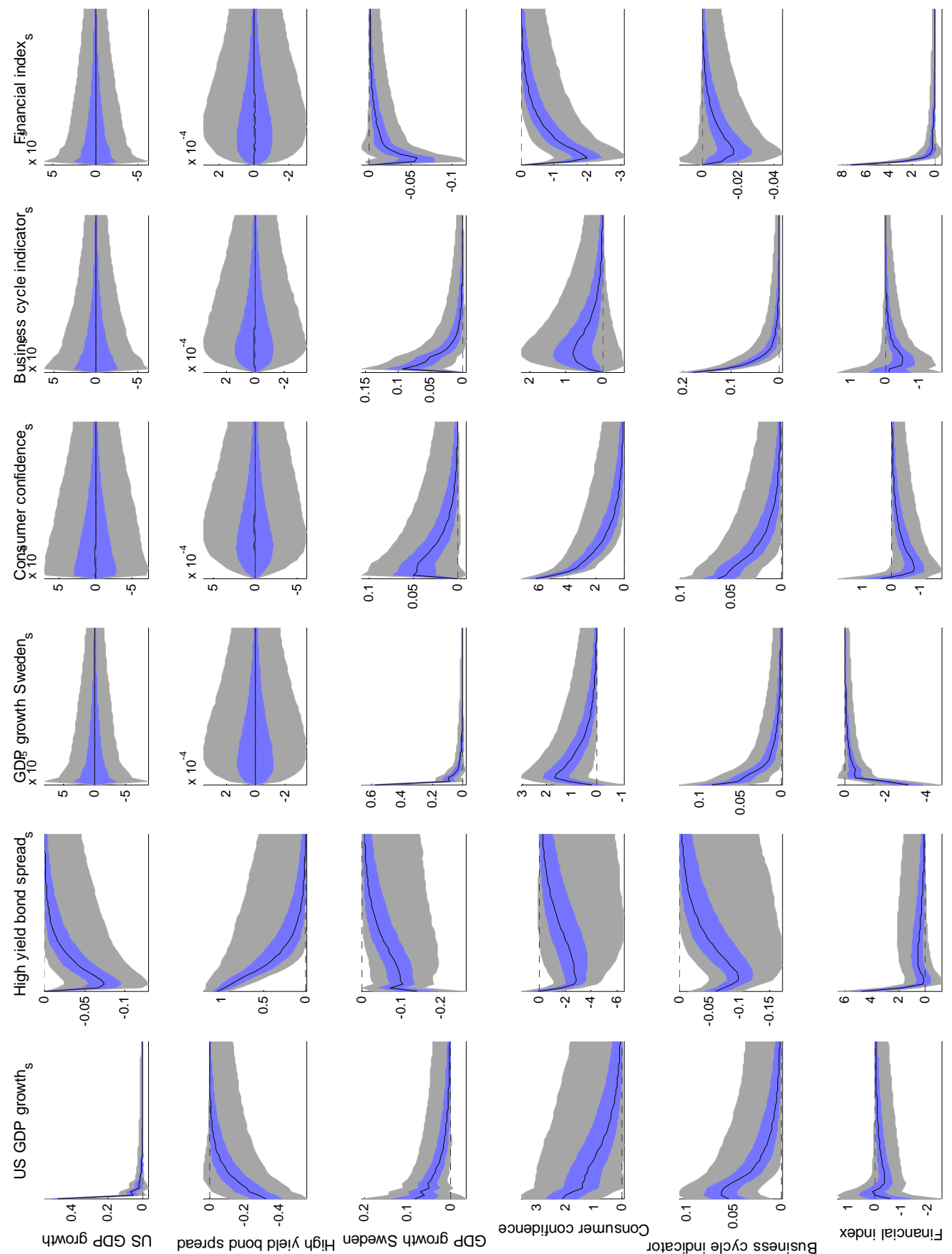

Note: Black line is the median. Coloured bands are 50 and 90 percent confidence bands. Maximum horizon is 40 quarters. 


\section{Titles in the Working Paper Series}

\begin{tabular}{|c|c|c|c|}
\hline No & Author & Title & Year \\
\hline 1 & $\begin{array}{l}\text { Warne, Anders and } \\
\text { Anders Vredin }\end{array}$ & $\begin{array}{l}\text { Current Account and Business Cycles: Stylized Facts } \\
\text { for Sweden }\end{array}$ & 1989 \\
\hline 2 & Östblom, Göran & $\begin{array}{l}\text { Change in Technical Structure of the Swedish Econ- } \\
\text { omy }\end{array}$ & 1989 \\
\hline 3 & Söderling, Paul & $\begin{array}{l}\text { Mamtax. A Dynamic CGE Model for Tax Reform } \\
\text { Simulations }\end{array}$ & 1989 \\
\hline 4 & $\begin{array}{l}\text { Kanis, Alfred and } \\
\text { Aleksander Markowski }\end{array}$ & $\begin{array}{l}\text { The Supply Side of the Econometric Model of the } \\
\text { NIER }\end{array}$ & 1990 \\
\hline 5 & Berg, Lennart & The Financial Sector in the SNEPQ Model & 1991 \\
\hline 6 & $\begin{array}{l}\text { Ågren, Anders and Bo } \\
\text { Jonsson }\end{array}$ & $\begin{array}{l}\text { Consumer Attitudes, Buying Intentions and Con- } \\
\text { sumption Expenditures. An Analysis of the Swedish } \\
\text { Household Survey Data }\end{array}$ & 1991 \\
\hline 7 & $\begin{array}{l}\text { Berg, Lennart and } \\
\text { Reinhold Bergström }\end{array}$ & $\begin{array}{l}\text { A Quarterly Consumption Function for Sweden 1979- } \\
1989\end{array}$ & 1991 \\
\hline 8 & Öller, Lars-Erik & $\begin{array}{l}\text { Good Business Cycle Forecasts- A Must for Stabiliza- } \\
\text { tion Policies }\end{array}$ & 1992 \\
\hline 9 & $\begin{array}{l}\text { Jonsson, Bo and An- } \\
\text { ders Ågren }\end{array}$ & $\begin{array}{l}\text { Forecasting Car Expenditures Using Household Sur- } \\
\text { vey Data }\end{array}$ & 1992 \\
\hline 10 & $\begin{array}{l}\text { Löfgren, Karl-Gustaf, } \\
\text { Bo Ranneby and Sara } \\
\text { Sjöstedt }\end{array}$ & $\begin{array}{l}\text { Forecasting the Business Cycle Not Using Minimum } \\
\text { Autocorrelation Factors }\end{array}$ & 1992 \\
\hline 11 & Gerlach, Stefan & $\begin{array}{l}\text { Current Quarter Forecasts of Swedish GNP Using } \\
\text { Monthly Variables }\end{array}$ & 1992 \\
\hline 12 & Bergström, Reinhold & $\begin{array}{l}\text { The Relationship Between Manufacturing Production } \\
\text { and Different Business Survey Series in Sweden }\end{array}$ & 1992 \\
\hline 13 & $\begin{array}{l}\text { Edlund, Per-Olov and } \\
\text { Sune Karlsson }\end{array}$ & $\begin{array}{l}\text { Forecasting the Swedish Unemployment Rate: VAR } \\
\text { vs. Transfer Function Modelling }\end{array}$ & 1992 \\
\hline 14 & $\begin{array}{l}\text { Rahiala, Markku and } \\
\text { Timo Teräsvirta }\end{array}$ & $\begin{array}{l}\text { Business Survey Data in Forecasting the Output of } \\
\text { Swedish and Finnish Metal and Engineering Indus- } \\
\text { tries: A Kalman Filter Approach }\end{array}$ & 1992 \\
\hline 15 & $\begin{array}{l}\text { Christofferson, An- } \\
\text { ders, Roland Roberts } \\
\text { and Ulla Eriksson }\end{array}$ & $\begin{array}{l}\text { The Relationship Between Manufacturing and Various } \\
\text { BTS Series in Sweden Illuminated by Frequency and } \\
\text { Complex Demodulate Methods }\end{array}$ & 1992 \\
\hline 16 & Jonsson, Bo & $\begin{array}{l}\text { Sample Based Proportions as Values on an Independ- } \\
\text { ent Variable in a Regression Model }\end{array}$ & 1992 \\
\hline 17 & Öller, Lars-Erik & $\begin{array}{l}\text { Eliciting Turning Point Warnings from Business Sur- } \\
\text { veys }\end{array}$ & 1992 \\
\hline 18 & Forster, Margaret M & $\begin{array}{l}\text { Volatility, Trading Mechanisms and International } \\
\text { Cross-Listing }\end{array}$ & 1992 \\
\hline 19 & Jonsson, Bo & $\begin{array}{l}\text { Prediction with a Linear Regression Model and Errors } \\
\text { in a Regressor }\end{array}$ & 1992 \\
\hline 20 & $\begin{array}{l}\text { Gorton, Gary and } \\
\text { Richard Rosen }\end{array}$ & $\begin{array}{l}\text { Corporate Control, Portfolio Choice, and the Decline } \\
\text { of Banking }\end{array}$ & 1993 \\
\hline 21 & $\begin{array}{l}\text { Gustafsson, Claes- } \\
\text { Håkan and Åke } \\
\text { Holmén }\end{array}$ & $\begin{array}{l}\text { The Index of Industrial Production - A Formal De- } \\
\text { scription of the Process Behind it }\end{array}$ & 1993 \\
\hline 22 & Karlsson, Tohmas & A General Equilibrium Analysis of the Swedish Tax & 1993 \\
\hline
\end{tabular}




\begin{tabular}{|c|c|c|c|}
\hline & & Reforms 1989-1991 & \\
\hline 23 & Jonsson, Bo & $\begin{array}{l}\text { Forecasting Car Expenditures Using Household Sur- } \\
\text { vey Data- A Comparison of Different Predictors }\end{array}$ & 1993 \\
\hline 24 & $\begin{array}{l}\text { Gennotte, Gerard and } \\
\text { Hayne Leland }\end{array}$ & Low Margins, Derivative Securitites and Volatility & 1993 \\
\hline 25 & $\begin{array}{l}\text { Boot, Arnoud W.A. } \\
\text { and Stuart I. } \\
\text { Greenbaum }\end{array}$ & Discretion in the Regulation of U.S. Banking & 1993 \\
\hline 26 & $\begin{array}{l}\text { Spiegel, Matthew and } \\
\text { Deane J. Seppi }\end{array}$ & $\begin{array}{l}\text { Does Round-the-Clock Trading Result in Pareto Im- } \\
\text { provements? }\end{array}$ & 1993 \\
\hline 27 & Seppi, Deane J. & $\begin{array}{l}\text { How Important are Block Trades in the Price Discov- } \\
\text { ery Process? }\end{array}$ & 1993 \\
\hline 28 & Glosten, Lawrence R. & Equilibrium in an Electronic Open Limit Order Book & 1993 \\
\hline 29 & $\begin{array}{l}\text { Boot, Arnoud W.A., } \\
\text { Stuart I Greenbaum } \\
\text { and Anjan V. Thakor }\end{array}$ & Reputation and Discretion in Financial Contracting & 1993 \\
\hline $30 \mathrm{a}$ & Bergström, Reinhold & $\begin{array}{l}\text { The Full Tricotomous Scale Compared with Net Bal- } \\
\text { ances in Qualitative Business Survey Data - Experi- } \\
\text { ences from the Swedish Business Tendency Surveys }\end{array}$ & 1993 \\
\hline $30 \mathrm{~b}$ & Bergström, Reinhold & $\begin{array}{l}\text { Quantitative Production Series Compared with } \\
\text { Qualiative Business Survey Series for Five Sectors of } \\
\text { the Swedish Manufacturing Industry }\end{array}$ & 1993 \\
\hline 31 & $\begin{array}{l}\text { Lin, Chien-Fu Jeff and } \\
\text { Timo Teräsvirta }\end{array}$ & $\begin{array}{l}\text { Testing the Constancy of Regression Parameters } \\
\text { Against Continous Change }\end{array}$ & 1993 \\
\hline 32 & $\begin{array}{l}\text { Markowski, Aleksan- } \\
\text { der and Parameswar } \\
\text { Nandakumar }\end{array}$ & $\begin{array}{l}\text { A Long-Run Equilibrium Model for Sweden. The } \\
\text { Theory Behind the Long-Run Solution to the } \\
\text { Econometric Model KOSMOS }\end{array}$ & 1993 \\
\hline 33 & $\begin{array}{l}\text { Markowski, Aleksan- } \\
\text { der and Tony Persson }\end{array}$ & $\begin{array}{l}\text { Capital Rental Cost and the Adjustment for the Ef- } \\
\text { fects of the Investment Fund System in the Econo- } \\
\text { metric Model Kosmos }\end{array}$ & 1993 \\
\hline 34 & $\begin{array}{l}\text { Kanis, Alfred and } \\
\text { Bharat Barot }\end{array}$ & On Determinants of Private Consumption in Sweden & 1993 \\
\hline 35 & $\begin{array}{l}\text { Kääntä, Pekka and } \\
\text { Christer Tallbom }\end{array}$ & $\begin{array}{l}\text { Using Business Survey Data for Forecasting Swedish } \\
\text { Quantitative Business Cycle Varable. A Kalman Filter } \\
\text { Approach }\end{array}$ & 1993 \\
\hline 36 & $\begin{array}{l}\text { Ohlsson, Henry and } \\
\text { Anders Vredin }\end{array}$ & $\begin{array}{l}\text { Political Cycles and Cyclical Policies. A New Test } \\
\text { Approach Using Fiscal Forecasts }\end{array}$ & 1993 \\
\hline 37 & $\begin{array}{l}\text { Markowski, Aleksan- } \\
\text { der and Lars Ernsäter }\end{array}$ & $\begin{array}{l}\text { The Supply Side in the Econometric Model KOS- } \\
\text { MOS }\end{array}$ & 1994 \\
\hline 38 & $\begin{array}{l}\text { Gustafsson, Claes- } \\
\text { Håkan }\end{array}$ & $\begin{array}{l}\text { On the Consistency of Data on Production, Deliver- } \\
\text { ies, and Inventories in the Swedish Manufacturing } \\
\text { Industry }\end{array}$ & 1994 \\
\hline 39 & $\begin{array}{l}\text { Rahiala, Markku and } \\
\text { Tapani Kovalainen }\end{array}$ & $\begin{array}{l}\text { Modelling Wages Subject to Both Contracted Incre- } \\
\text { ments and Drift by Means of a Simultaneous- } \\
\text { Equations Model with Non-Standard Error Structure }\end{array}$ & 1994 \\
\hline 40 & $\begin{array}{l}\text { Öller, Lars-Erik and } \\
\text { Christer Tallbom }\end{array}$ & $\begin{array}{l}\text { Hybrid Indicators for the Swedish Economy Based on } \\
\text { Noisy Statistical Data and the Business Tendency } \\
\text { Survey }\end{array}$ & 1994 \\
\hline 41 & Östblom, Göran & A Converging Triangularization Algorithm and the & 1994 \\
\hline
\end{tabular}




\begin{tabular}{|c|c|c|c|}
\hline & & Intertemporal Similarity of Production Structures & \\
\hline $42 \mathrm{a}$ & $\begin{array}{l}\text { Markowski, Aleksan- } \\
\text { der }\end{array}$ & $\begin{array}{l}\text { Labour Supply, Hours Worked and Unemployment in } \\
\text { the Econometric Model KOSMOS }\end{array}$ & 1994 \\
\hline $42 \mathrm{~b}$ & $\begin{array}{l}\text { Markowski, Aleksan- } \\
\text { der }\end{array}$ & $\begin{array}{l}\text { Wage Rate Determination in the Econometric Model } \\
\text { KOSMOS }\end{array}$ & 1994 \\
\hline 43 & $\begin{array}{l}\text { Ahlroth, Sofia, Anders } \\
\text { Björklund and Anders } \\
\text { Forslund }\end{array}$ & The Output of the Swedish Education Sector & 1994 \\
\hline $44 \mathrm{a}$ & $\begin{array}{l}\text { Markowski, Aleksan- } \\
\text { der }\end{array}$ & $\begin{array}{l}\text { Private Consumption Expenditure in the Econometric } \\
\text { Model KOSMOS }\end{array}$ & 1994 \\
\hline $44 \mathrm{~b}$ & $\begin{array}{l}\text { Markowski, Aleksan- } \\
\text { der }\end{array}$ & $\begin{array}{l}\text { The Input-Output Core: Determination of Inventory } \\
\text { Investment and Other Business Output in the } \\
\text { Econometric Model KOSMOS }\end{array}$ & 1994 \\
\hline 45 & Bergström, Reinhold & $\begin{array}{l}\text { The Accuracy of the Swedish National Budget Fore- } \\
\text { casts 1955-92 }\end{array}$ & 1995 \\
\hline 46 & Sjöö, Boo & $\begin{array}{l}\text { Dynamic Adjustment and Long-Run Economic Sta- } \\
\text { bility }\end{array}$ & 1995 \\
\hline $47 \mathrm{a}$ & $\begin{array}{l}\text { Markowski, Aleksan- } \\
\text { der }\end{array}$ & $\begin{array}{l}\text { Determination of the Effective Exchange Rate in the } \\
\text { Econometric Model KOSMOS }\end{array}$ & 1995 \\
\hline $47 \mathrm{~b}$ & $\begin{array}{l}\text { Markowski, Aleksan- } \\
\text { der }\end{array}$ & $\begin{array}{l}\text { Interest Rate Determination in the Econometric } \\
\text { Model KOSMOS }\end{array}$ & 1995 \\
\hline 48 & Barot, Bharat & $\begin{array}{l}\text { Estimating the Effects of Wealth, Interest Rates and } \\
\text { Unemployment on Private Consumption in Sweden }\end{array}$ & 1995 \\
\hline 49 & Lundvik, Petter & Generational Accounting in a Small Open Economy & 1996 \\
\hline 50 & $\begin{array}{l}\text { Eriksson, Kimmo, } \\
\text { Johan Karlander and } \\
\text { Lars-Erik Öller }\end{array}$ & Hierarchical Assignments: Stability and Fairness & 1996 \\
\hline 51 & Url, Thomas & Internationalists, Regionalists, or Eurocentrists & 1996 \\
\hline 52 & Ruist, Erik & Temporal Aggregation of an Econometric Equation & 1996 \\
\hline 53 & $\begin{array}{l}\text { Markowski, Aleksan- } \\
\text { der }\end{array}$ & $\begin{array}{l}\text { The Financial Block in the Econometric Model } \\
\text { KOSMOS }\end{array}$ & 1996 \\
\hline 54 & Östblom, Göran & $\begin{array}{l}\text { Emissions to the Air and the Allocation of GDP: } \\
\text { Medium Term Projections for Sweden. In Conflict } \\
\text { with the Goals of } \mathrm{SO}_{2}, \mathrm{SO}_{2} \text { and NOX Emissions for } \\
\text { Year } 2000\end{array}$ & 1996 \\
\hline 55 & $\begin{array}{l}\text { Koskinen, Lasse, } \\
\text { Aleksander Markows- } \\
\text { ki, Parameswar Nan- } \\
\text { dakumar and Lars- } \\
\text { Erik Öller }\end{array}$ & Three Seminar Papers on Output Gap & 1997 \\
\hline 56 & $\begin{array}{l}\text { Oke, Timothy and } \\
\text { Lars-Erik Öller }\end{array}$ & Testing for Short Memory in a VARMA Process & 1997 \\
\hline 57 & $\begin{array}{l}\text { Johansson, Anders } \\
\text { and Karl-Markus Mo- } \\
\text { dén }\end{array}$ & Investment Plan Revisions and Share Price Volatility & 1997 \\
\hline 58 & Lyhagen, Johan & $\begin{array}{l}\text { The Effect of Precautionary Saving on Consumption } \\
\text { in Sweden }\end{array}$ & 1998 \\
\hline 59 & $\begin{array}{l}\text { Koskinen, Lasse and } \\
\text { Lars-Erik Öller }\end{array}$ & $\begin{array}{l}\text { A Hidden Markov Model as a Dynamic Bayesian } \\
\text { Classifier, with an Application to Forecasting Busi- } \\
\text { ness-Cycle Turning Points }\end{array}$ & 1998 \\
\hline
\end{tabular}




\begin{tabular}{|c|c|c|c|}
\hline 60 & $\begin{array}{l}\text { Kragh, Börje and } \\
\text { Aleksander Markowski }\end{array}$ & $\begin{array}{l}\text { Kofi - a Macromodel of the Swedish Financial Mar- } \\
\text { kets }\end{array}$ & 1998 \\
\hline 61 & $\begin{array}{l}\text { Gajda, Jan B. and } \\
\text { Aleksander Markowski }\end{array}$ & $\begin{array}{l}\text { Model Evaluation Using Stochastic Simulations: The } \\
\text { Case of the Econometric Model KOSMOS }\end{array}$ & 1998 \\
\hline 62 & Johansson, Kerstin & Exports in the Econometric Model KOSMOS & 1998 \\
\hline 63 & Johansson, Kerstin & $\begin{array}{l}\text { Permanent Shocks and Spillovers: A Sectoral Ap- } \\
\text { proach Using a Structural VAR }\end{array}$ & 1998 \\
\hline 64 & $\begin{array}{l}\text { Öller, Lars-Erik and } \\
\text { Bharat Barot }\end{array}$ & Comparing the Accuracy of European GDP Forecasts & 1999 \\
\hline 65 & $\begin{array}{l}\text { Huhtala, Anni and } \\
\text { Eva Samakovlis }\end{array}$ & $\begin{array}{l}\text { Does International Harmonization of Environmental } \\
\text { Policy Instruments Make Economic Sense? The Case } \\
\text { of Paper Recycling in Europe }\end{array}$ & 1999 \\
\hline 66 & Nilsson, Charlotte & $\begin{array}{l}\text { A Unilateral Versus a Multilateral Carbon Dioxide Tax } \\
\text { - A Numerical Analysis With The European Model } \\
\text { GEM-E3 }\end{array}$ & 1999 \\
\hline 67 & $\begin{array}{l}\text { Braconier, Henrik and } \\
\text { Steinar Holden }\end{array}$ & $\begin{array}{l}\text { The Public Budget Balance - Fiscal Indicators and } \\
\text { Cyclical Sensitivity in the Nordic Countries }\end{array}$ & 1999 \\
\hline 68 & Nilsson, Kristian & $\begin{array}{l}\text { Alternative Measures of the Swedish Real Exchange } \\
\text { Rate }\end{array}$ & 1999 \\
\hline 69 & Östblom, Göran & $\begin{array}{l}\text { An Environmental Medium Term Economic Model - } \\
\text { EMEC }\end{array}$ & 1999 \\
\hline 70 & $\begin{array}{l}\text { Johnsson, Helena and } \\
\text { Peter Kaplan }\end{array}$ & $\begin{array}{l}\text { An Econometric Study of Private Consumption Ex- } \\
\text { penditure in Sweden }\end{array}$ & 1999 \\
\hline 71 & $\begin{array}{l}\text { Arai, Mahmood and } \\
\text { Fredrik Heyman }\end{array}$ & $\begin{array}{l}\text { Permanent and Temporary Labour: Job and Worker } \\
\text { Flows in Sweden 1989-1998 }\end{array}$ & 2000 \\
\hline 72 & $\begin{array}{l}\text { Öller, Lars-Erik and } \\
\text { Bharat Barot }\end{array}$ & $\begin{array}{l}\text { The Accuracy of European Growth and Inflation } \\
\text { Forecasts }\end{array}$ & 2000 \\
\hline 73 & Ahlroth, Sofia & $\begin{array}{l}\text { Correcting Net Domestic Product for Sulphur Diox- } \\
\text { ide and Nitrogen Oxide Emissions: Implementation } \\
\text { of a Theoretical Model in Practice }\end{array}$ & 2000 \\
\hline 74 & $\begin{array}{l}\text { Andersson, Michael } \\
\text { K. And Mikael P. } \\
\text { Gredenhoff } \\
\end{array}$ & $\begin{array}{l}\text { Improving Fractional Integration Tests with Boot- } \\
\text { strap Distribution }\end{array}$ & 2000 \\
\hline 75 & $\begin{array}{l}\text { Nilsson, Charlotte and } \\
\text { Anni Huhtala }\end{array}$ & $\begin{array}{l}\text { Is } \mathrm{CO}_{2} \text { Trading Always Beneficial? A CGE-Model } \\
\text { Analysis on Secondary Environmental Benefits }\end{array}$ & 2000 \\
\hline 76 & Skånberg, Kristian & $\begin{array}{l}\text { Constructing a Partially Environmentally Adjusted } \\
\text { Net Domestic Product for Sweden } 1993 \text { and } 1997\end{array}$ & 2001 \\
\hline 77 & $\begin{array}{l}\text { Huhtala, Anni, Annie } \\
\text { Toppinen and Mattias } \\
\text { Boman, }\end{array}$ & $\begin{array}{l}\text { An Environmental Accountant's Dilemma: Are } \\
\text { Stumpage Prices Reliable Indicators of Resource Scar- } \\
\text { city? }\end{array}$ & 2001 \\
\hline 78 & Nilsson, Kristian & $\begin{array}{l}\text { Do Fundamentals Explain the Behavior of the Real } \\
\text { Effective Exchange Rate? }\end{array}$ & 2002 \\
\hline 79 & Bharat, Barot & $\begin{array}{l}\text { Growth and Business Cycles for the Swedish Econ- } \\
\text { omy }\end{array}$ & 2002 \\
\hline 80 & Bharat, Barot & $\begin{array}{l}\text { House Prices and Housing Investment in Sweden and } \\
\text { the United Kingdom. Econometric Analysis for the } \\
\text { Period 1970-1998 }\end{array}$ & 2002 \\
\hline 81 & Hjelm, Göran & $\begin{array}{l}\text { Simultaneous Determination of NAIRU, Output } \\
\text { Gaps and Structural Budget Balances: Swedish Evi- } \\
\text { dence }\end{array}$ & 2003 \\
\hline
\end{tabular}




\begin{tabular}{|c|c|c|c|}
\hline 82 & $\begin{array}{l}\text { Huhtala, Anni and } \\
\text { Eva Samalkovis }\end{array}$ & Green Accounting, Air Pollution and Health & 2003 \\
\hline 83 & Lindström, Tomas & $\begin{array}{l}\text { The Role of High-Tech Capital Formation for Swed- } \\
\text { ish Productivity Growth }\end{array}$ & 2003 \\
\hline 84 & $\begin{array}{l}\text { Hansson, Jesper, Per } \\
\text { Jansson and Mårten } \\
\text { Löf }\end{array}$ & $\begin{array}{l}\text { Business survey data: do they help in forecasting the } \\
\text { macro economy? }\end{array}$ & 2003 \\
\hline 85 & $\begin{array}{l}\text { Boman, Mattias, Anni } \\
\text { Huhtala, Charlotte } \\
\text { Nilsson, Sofia Ahl- } \\
\text { roth, Göran Bostedt, } \\
\text { Leif Mattson and Pei- } \\
\text { chen Gong }\end{array}$ & $\begin{array}{l}\text { Applying the Contingent Valuation Method in Re- } \\
\text { source Accounting: A Bold Proposal }\end{array}$ & \\
\hline 86 & Gren, Ing-Marie & Monetary Green Accounting and Ecosystem Services & 2003 \\
\hline 87 & $\begin{array}{l}\text { Samakovlis, Eva, Anni } \\
\text { Huhtala, Tom Bellan- } \\
\text { der and Magnus Svar- } \\
\text { tengren }\end{array}$ & $\begin{array}{l}\text { Air Quality and Morbidity: Concentration-response } \\
\text { Relationships for Sweden }\end{array}$ & 2004 \\
\hline 88 & $\begin{array}{l}\text { Alsterlind, Jan, Alek } \\
\text { Markowski and Kristi- } \\
\text { an Nilsson }\end{array}$ & $\begin{array}{l}\text { Modelling the Foreign Sector in a Macroeconometric } \\
\text { Model of Sweden }\end{array}$ & 2004 \\
\hline 89 & Lindén, Johan & The Labor Market in KIMOD & 2004 \\
\hline 90 & $\begin{array}{l}\text { Braconier, Henrik and } \\
\text { Tomas Forsfält }\end{array}$ & $\begin{array}{l}\text { A New Method for Constructing a Cyclically Adjusted } \\
\text { Budget Balance: the Case of Sweden }\end{array}$ & 2004 \\
\hline 91 & $\begin{array}{l}\text { Hansen, Sten and } \\
\text { Tomas Lindström }\end{array}$ & Is Rising Returns to Scale a Figment of Poor Data? & 2004 \\
\hline 92 & Hjelm, Göran & $\begin{array}{l}\text { When Are Fiscal Contractions Successful? Lessons for } \\
\text { Countries Within and Outside the EMU }\end{array}$ & 2004 \\
\hline 93 & $\begin{array}{l}\text { Östblom, Göran and } \\
\text { Samakovlis, Eva }\end{array}$ & $\begin{array}{l}\text { Costs of Climate Policy when Pollution Affects } \\
\text { Health and Labour Productivity. A General } \\
\text { Equilibrium Analysis Applied to Sweden }\end{array}$ & 2004 \\
\hline 94 & $\begin{array}{l}\text { Forslund Johanna, } \\
\text { Eva Samakovlis and } \\
\text { Maria Vredin Johans- } \\
\text { son }\end{array}$ & $\begin{array}{l}\text { Matters Risk? The Allocation of Government Subsi- } \\
\text { dies for Remediation of Contaminated Sites under the } \\
\text { Local Investment Programme }\end{array}$ & 2006 \\
\hline 95 & $\begin{array}{l}\text { Erlandsson Mattias } \\
\text { and Alek Markowski }\end{array}$ & $\begin{array}{l}\text { The Effective Exchange Rate Index KIX - Theory } \\
\text { and Practice }\end{array}$ & 2006 \\
\hline 96 & $\begin{array}{l}\text { Östblom Göran and } \\
\text { Charlotte Berg }\end{array}$ & The EMEC model: Version 2.0 & 2006 \\
\hline 97 & $\begin{array}{l}\text { Hammar, Henrik, } \\
\text { Tommy Lundgren and } \\
\text { Magnus Sjöström } \\
\end{array}$ & $\begin{array}{l}\text { The significance of transport costs in the Swedish } \\
\text { forest industry }\end{array}$ & 2006 \\
\hline 98 & Barot, Bharat & $\begin{array}{l}\text { Empirical Studies in Consumption, House Prices and } \\
\text { the Accuracy of European Growth and Inflation } \\
\text { Forecasts }\end{array}$ & 2006 \\
\hline 99 & Hjelm, Göran & $\begin{array}{l}\text { Kan arbetsmarknadens parter minska jämviktsarbets- } \\
\text { lösheten? Teori och modellsimuleringar }\end{array}$ & 2006 \\
\hline 100 & $\begin{array}{l}\text { Bergvall, Anders, To- } \\
\text { mas Forsfält, Göran } \\
\text { Hjelm, }\end{array}$ & $\begin{array}{l}\text { KIMOD 1.0 Documentation of NIER's Dynamic } \\
\text { Macroeconomic General Equilibrium Model of the } \\
\text { Swedish Economy }\end{array}$ & 2007 \\
\hline
\end{tabular}




\begin{tabular}{|c|c|c|c|}
\hline & $\begin{array}{l}\text { Jonny Nilsson and } \\
\text { Juhana Vartiainen }\end{array}$ & & \\
\hline 101 & Östblom, Göran & $\begin{array}{l}\text { Nitrogen and Sulphur Outcomes of a Carbon Emis- } \\
\text { sions Target Excluding Traded Allowances - } \\
\text { An Input-Output Analysis of the Swedish Case }\end{array}$ & 2007 \\
\hline 102 & $\begin{array}{l}\text { Hammar, Henrik and } \\
\text { Âsa Löfgren }\end{array}$ & $\begin{array}{l}\text { Explaining adoption of end of pipe solutions and } \\
\text { clean technologies - Determinants of firms' invest- } \\
\text { ments for reducing emissions to air in four sextors in } \\
\text { Sweden }\end{array}$ & 2007 \\
\hline 103 & $\begin{array}{l}\text { Östblom, Göran and } \\
\text { Henrik Hammar }\end{array}$ & $\begin{array}{l}\text { Outcomes of a Swedish Kilometre Tax. An Analysis } \\
\text { of Economic Effects and Effects on NOx Emissions }\end{array}$ & 2007 \\
\hline 104 & $\begin{array}{l}\text { Forsfält, Tomas, } \\
\text { Johnny Nilsson and } \\
\text { Juhana Vartianinen }\end{array}$ & $\begin{array}{l}\text { Modellansatser i Konjunkturinstitutets medelfrist- } \\
\text { prognoser }\end{array}$ & 208 \\
\hline 105 & Samakovlis, Eva & $\begin{array}{l}\text { How are Green National Accounts Produced in Prac- } \\
\text { tice? }\end{array}$ & 2008 \\
\hline 107 & $\begin{array}{l}\text { Forslund, Johanna, } \\
\text { Per Johansson, Eva } \\
\text { Samakovlis and Maria } \\
\text { Vredin Johansson }\end{array}$ & $\begin{array}{l}\text { Can we by time? Evaluation. Evaluation of the } \\
\text { government's directed grant to remediation in Sweden }\end{array}$ & 2009 \\
\hline 108 & $\begin{array}{l}\text { Forslund, Johanna } \\
\text { Eva Samakovlis, Maria } \\
\text { Vredin Johansson and } \\
\text { Lars Barregård }\end{array}$ & $\begin{array}{l}\text { Does Remediation Save Lives? } \\
\text { On the Cost of Cleaning Up } \\
\text { Arsenic-Contaminated } \\
\text { Sites in Sweden }\end{array}$ & 2009 \\
\hline 109 & $\begin{array}{l}\text { Sjöström, Magnus and } \\
\text { Göran Östblom }\end{array}$ & $\begin{array}{l}\text { Future Waste Scenarios for Sweden on the Basis of a } \\
\text { CGE-model }\end{array}$ & 2009 \\
\hline 110 & Österholm, Pär & $\begin{array}{l}\text { The Effect on the Swedish Real Economy of the Fi- } \\
\text { nancial Crisis }\end{array}$ & 2009 \\
\hline
\end{tabular}

